\title{
Antiviral Properties of Orthosiphon stamineus Aqueous Extract in Herpes Simplex Virus Type 1 Infected Cells
}

(Sifat Antivirus Akues Ekstrak Orthosiphon stamineus dalam Sel Terjangkit Virus Herpes Simpleks Jenis 1)

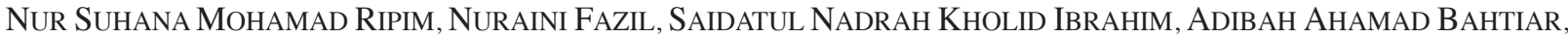 \\ YIP CHEE WAI, NAZLINA IBRAHIM \& NOREFRINA SHAFINAZ MD NOR*
}

\begin{abstract}
A study was conducted to investigate the antiviral activity of aqueous extracts from Orthosiphon stamineus (OS). Extraction was done using different parts of oS. The whole plant except root (WPOS), leaves (LOS) and flowers (FOS) of os were extracted using aqueous extraction method. Cytotoxicity was assessed using 3-(4,5-dimethylthiazol-2,5-diphenyl tetrazolium bromide (MTT) assay. Plaque reduction assays were carried out to evaluate the antiviral activity of os extract against herpes simplex virus type 1 (HSV-1). These include post-treatment, pre-treatment and virucidal assays. High antiviral activity was observed in post-treatment and virucidal assay with $100 \%$ reduction of HSV-1 plaque at $0.39 \mathrm{mg} /$ $m L$ in LOS, FOS and WPOS. In pre-treatment assay, 79\%, 84\% and 97\% plaque reduction using the same concentration was observed in FOS, LOS and WPOS, respectively. In conclusion, this study showed that OS aqueous extract has promising potential to be explored as anti-HSV-1 agent regardless of the mode of treatment.
\end{abstract}

Keywords: Cytotoxicity; ethnopharmacology; MTT; plaque reduction assay; virucidal

\section{ABSTRAK}

Suatu kajian telah dijalankan untuk menguji aktiviti antivirus bagi ekstrak akuas daripada Orthosiphon stamineus (OS). Pengekstrakan telah dijalankan dengan menggunakan bahagian os yang berbeza. Seluruh tumbuhan kecuali akar (WPOS), daun (LOS) dan bunga (FOS) OS telah diekstrak melalui kaedah pengekstrakan akues. Ujian kesitotoksikan telah dijalankan dengan asai 3-(4,5- dimetiltiazol-2,5-diphenil tetrazolium bromida (MTT). Asai pengurangan plak telah dilakukan untuk mengkaji aktiviti antivirus ekstrak OS terhadap virus herpes simpleks jenis 1 (HSV-1). Antaranya ialah asai pasca-rawatan, pra-rawatan dan virusid. Aktiviti antivirus yang tinggi telah diperhatikan dalam asai virusid dan pasca-rawatan dengan 100\% pengurangan plak HSV-1 pada $0.39 \mathrm{mg} / \mathrm{mL}$ bagi LOS, FOS dan WPOS. Dalam pra-rawatan, sebanyak 79\%, 84\% dan 97\% pengurangan plak pada kepekatan ekstrak yang sama telah dicerap masing-masing dalam FOS, LOS dan WPOS. Secara keseluruhan, kajian ini telah menunjukkan bahawa ekstrak os mempunyai potensi yang ting gi untuk dieksplotasi sebagai agen anti-HSV-1 tanpa mengira mod rawatan.

Kata kunci: Asai pengurangan plak; etnofarmakologi; kesitotoksikan; MTT; virusid

\section{INTRODUCTION}

Orthosiphon stamineus or misai kucing is one of the unique medicinal herbs which has been reported to exert dynamic pharmacological properties not only traditionally but also scientifically proven. Extract of os has been reported to exhibit comparable antioxidant activity with pure quercetin and synthetic antioxidant, BHA (Akowuah et al. 2005). Research by Al-suede et al. (2012) showed that OS also exhibited anti-tumour activity where os extract significantly inhibited orthotopically implanted colon tumor in immunocompromised mouse xenograft model. In addition, OS extract also showed antibacterial activity against Vibrio parahaemolyticus, a food borne bacteria (Ho et al. 2010) and also antifungal properties against R. solani, B. cinerea, F. solani and Colletotricum capsisi (Amzad et. al 2007).

Herpes simplex virus (HSV) is a double-stranded DNA virus with a genome size of at least $152 \mathrm{kbp}$. The virion is made up of four major components which are the viral DNA, icosahedral capsid, tegument which surrounds the capsid and envelope (Roizman \& Knipe 1993). The ability to invade and replicate in human central nervous system followed by establishment of latent infection are two unique biological properties of HSV and these biological properties enable reactivation of the latent virus (Whitley \& Roizman 2001). Acyclovir (ACV), a synthetic acyclic purine nucleoside analogue has been widely prescribed for decades as a therapy for HSV infections and still available to date. However, there have been reports on ACV resistant strains in cases involving immunocompromised individual and this resistance occurs through mutations in the viralencoded thymidine kinase (TK) gene as well as on DNA polymerase loci (Schnipper \& Crumpacker 1980; Whitley \& Roizman 2001). In order to combat this resistant HSV-1 strain, new antiviral agents with different mode of actions are indeed important. 
Reported scientific research supported by empirical data has shown that os has the potential in treating various ailments involving multiple organ illnesses, cancer and infection of pathogenic fungi and bacteria. However, to date none has reported on the aqueous extract activity of OS against virus. To the best of our knowledge, this will be the first study to report on antiviral activity of OS aqueous extract against HSV-1. Therefore, the aim of this study was to investigate the potential of os aqueous extract as an antiviral agent against HSV-1 infection.

\section{MATERIALS AND METHODS}

\section{PLANT MATERIAL}

Dried OS plant was supplied by Ladang Herba Ya'acob Berkat Enterprise, Bukit Katil, Melaka.

\section{CELL AND VIRUS}

Vero cell from American Type Culture Collection (ATCC) CCL-81 was used for both cytotoxicity and antiviral test. Dulbecco's Modified Eagle's Medium (DMEM) (SigmaAldrich, USA) supplemented with 5\% fetal bovine serum (FBS) (Sigma- Aldrich, USA) was used for cell maintenance throughout the experiment. Clinical strain of HSV-1 used was obtained from the stock culture of Faculty Science and Technology, Universiti Kebangsaan Malaysia. Briefly, the virus was propagated in vero cells, harvested and titrated using plaque assay as described by Nguyen et al. (2005).

\section{PREPARATION OF AQUEOUS EXTRACTS}

Dried os leaves, flowers and the whole parts of the plant (except root) were finely ground and then extracted using deionized water with a ratio of extract to water of 10:1 according to the method used by Li (2000) with slight modification. The extract was boiled for $2 \mathrm{~h}$. The extract was then centrifuged and stored at $-20^{\circ} \mathrm{C}$. Freeze dry technique was performed to lyophilize the extract. Three abbreviations used to represent OS extract, namely WPOS which refers to whole plant extract, FOS which refers to flower extract and LOS which refers to leaves extract.

\section{CYTOTOXICITY TEST}

Cytotoxicity test was conducted based on Mossman (1983). Briefly, lyophilized extracts were dissolved in growth medium (DMEM with 5\% FBS) with starting concentration of $10 \mathrm{mg} / \mathrm{mL}$. Two-fold serial dilution was done on each extract until a final concentration of $0.005 \mathrm{mg} / \mathrm{mL}$. Confluent Vero cells $\left(2.0 \times 10^{4}\right.$ cell $/$ well) grown in 96-well microtitre plate were treated with different concentrations of extract. After $48 \mathrm{~h}$ of incubation, 3-(4,5-dimethylthiazol-2-yl)-2,5-diphenyl tetrazolium bromide (MTT) was added into each well and was further incubated for $3 \mathrm{~h}$. Excess MTT was removed and $100 \mu \mathrm{L}$ of dimethylsulfoxide (DMSO) was added. The absorbance was measured at $540 \mathrm{~nm}$ by using microplate reader (Chromate 4300, Awareness Technology, USA). Percentage of cell viability was calculated and the $\mathrm{CC}_{50}$ value was obtained directly from graph of cell population versus extract concentration.

\section{ANTIVIRAL ASSAY}

Antiviral assays composed of post-treatment, pre-treatment and virucidal assays.

Post-treatment assay: Vero cells $\left(2.0 \times 10^{5}\right.$ cell/well $)$ were seeded into 12 well plate and incubated overnight. Upon confluency, cells were inoculated with $200 \mu \mathrm{L}$ of virus at $50 \mathrm{PFU}$ (plaque forming unit). Cells were incubated for $2 \mathrm{~h}$ to allow virus adsorption. After adsorption period, DMEM+methylcellulose was mixed with six concentrations of extracts and added into all test wells. For WPOS extract, the concentrations used were ranged between 0.0977 and 50 $\mathrm{mg} / \mathrm{mL}$ while for FOS and LOS extracts, the concentrations used were ranged between 0.01 and $0.39 \mathrm{mg} / \mathrm{mL}$. Cells were then incubated for $48 \mathrm{~h}$. After incubation, cells were stained using crystal violet and plaques were counted according to Dargan (1998).

Pre-treatment assay: Vero cells $\left(2.0 \times 10^{5}\right.$ cell/well $)$ were seeded in 12 well plate and incubated overnight. Cells were pre-treated with six concentrations of extracts for $24 \mathrm{~h}$ before being removed and infected with $200 \mu \mathrm{L}$ of virus at $50 \mathrm{PFU}$. For WPOS extract, the concentrations used were the same as in post-treatment assay. For FOS and LOS extracts, the concentrations used were $0.01,0.02$, $0.05,0.1,0.2$ and $0.39 \mathrm{mg} / \mathrm{mL}$. After adsorption period, DMEM+methylcellulose was added and incubated for $48 \mathrm{~h}$. After incubation, cells were stained using crystal violet and plaques were counted. Infected cells treated with 5 $\mu \mathrm{M}$ acyclovir (ACV) was used as positive control while infected cells without treatment was used as negative control. Selective Index, SI $\left(\mathrm{CC}_{50} / \mathrm{EC}_{50}\right.$ ratio $)$ was used to determine os efficiency as a potential antiviral agent.

Virucidal assay: This test was carried out based on Shogan et al. (2006). High virus titre ( $\left.10^{6} \mathrm{PFU}\right)$ was exposed to 0.39 $\mathrm{mg} / \mathrm{mL}$ of extracts for 30,60 and $90 \mathrm{~min}$ at $37^{\circ} \mathrm{C}$. Virus with DMEM only was used as negative control. After incubation, all tubes were diluted and titrated based on Blaho et al. (2005). Percentage of titer reduction was calculated by subtracting virus titer of control with treated sample (virus exposed to extracts).

\section{RESULTS}

\section{CYTOTOXICITY EVALUATION OF WPOS EXTRACT}

The aim of cytotoxicity evaluation was to determine the cytotoxic concentration that kills $50 \%$ cell population which is known as $\mathrm{CC}_{50}$ value. This value is used to define the upper-limit which needs to be used in the subsequent 


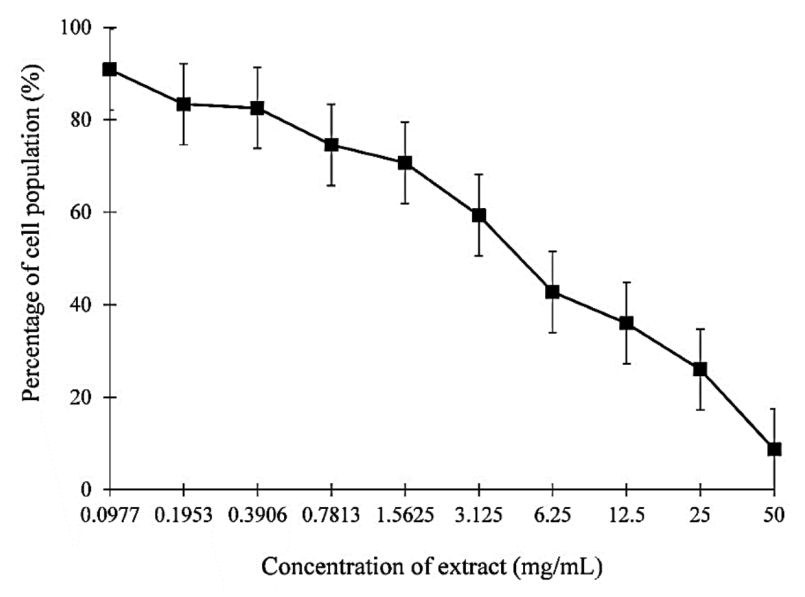

FIGURE 1. Effect of different concentration of WPOS extract towards the population of Vero cells

antiviral studies. In this assay, the $\mathrm{CC}_{50}$ value of WPOS extract was determined at $3.125 \mathrm{mg} / \mathrm{mL}$. Figure 1 shows the percentage of cell population versus concentration of WPOS extract. Thus, maximum concentration that was used in the subsequent antiviral studies was fixed at $3.125 \mathrm{mg} / \mathrm{mL}$.

\section{ANTI-HSV-1 ACTIVITY OF WPOS}

Plaque reduction assays were done to screen for anti-HSV-1 activity using WPOS extract with different concentrations. Figure 2(A), 2(B) and 2(C) shows the percentage of plaque reduction in post-treatment, pre-treatment and virucidal assays, respectively. The results from posttreatment assay showed that $100 \%$ plaque reduction was achieved at a minimum concentration of $0.39 \mathrm{mg} / \mathrm{mL}$. In pre-treatment assay, more than $95 \%$ plaque reduction was observed at $0.39 \mathrm{mg} / \mathrm{mL}$. For virucidal assay, $0.39 \mathrm{mg} /$ $\mathrm{mL}$ of WPOS extract was used since it showed more than 95\% plaque reduction both pre- and post-treatment assays. When HSV-1 was exposed to $0.39 \mathrm{mg} / \mathrm{mL}$ extract for 30 , 60 and $90 \mathrm{~min}, 100 \%$ plaque reduction was observed. This assay showed that, a minimum of $30 \mathrm{~min}$ time exposure of extract on virus was sufficient to gain $100 \%$ inhibition of HSV-1 plaque.

\section{CYTOTOXICITY EVALUATION OF FOS AND LOS EXTRACTS}

Different plant parts might contribute to different degree of toxicity on cells. Therefore, $\mathrm{CC}_{50}$ value for FOS and LOS extracts were determined in order to get safe range for the subsequent antiviral tests. Maximum concentration of FOS and LOS extracts used was $5 \mathrm{mg} / \mathrm{mL}$ since WPOS extract have a $\mathrm{CC}_{50}$ of $3.125 \mathrm{mg} / \mathrm{mL}$. This value was chosen to take into consideration that certain parts of the plants might harbor certain compounds that contribute to higher toxicity. In this assay, the $\mathrm{CC}_{50}$ for FOS extract was determined to be $1.269 \mathrm{mg} / \mathrm{mL}$. Lower concentration of $\mathrm{CC}_{50}$ was observed for LOS extract at $0.766 \mathrm{mg} / \mathrm{mL}$ (Figure 3).

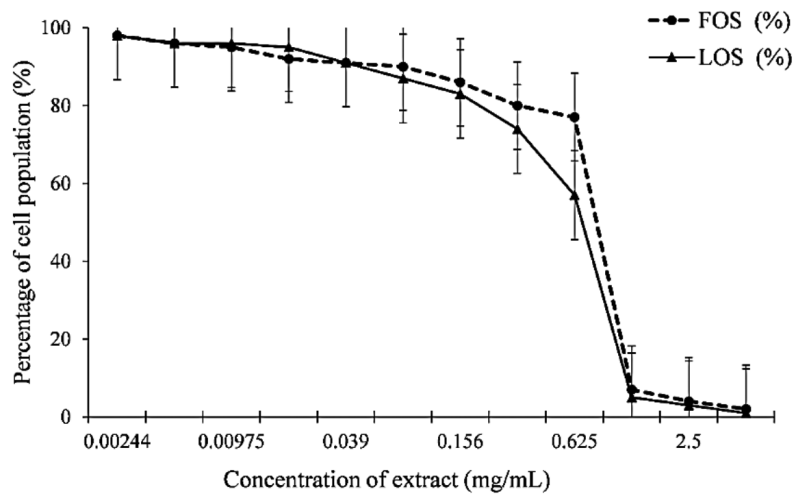

FIGURE 3. Effect of different concentration of FOS and LOS extracts towards population of Vero cells

\section{ANTI-HSV-1 ACTIVITY OF FOS AND LOS EXTRACTS}

Following anti-HSV-1 activity screening of WPOS extract, determination of specific part of the plant that contributed to the high antiviral activity observed was done. Figures 4 and 5 show the results obtained from antiviral assays using FOS and LOS extracts, respectively. In post-treatment

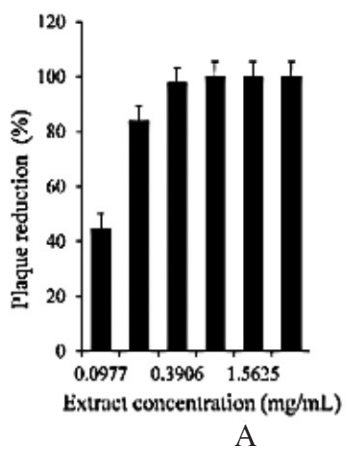

A
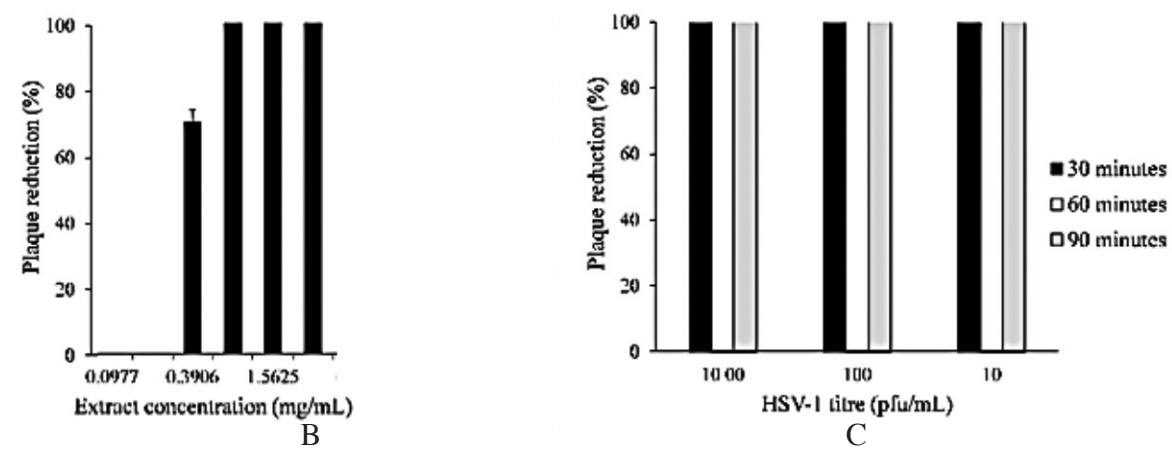

C

FIGURE 2. Antiviral activities of WPOS extract against HSV-1 via post-treatment assay

(A), pre-treatment assay (B) and virucidal assay (C) 
assay, $100 \%$ plaque reduction was observed in both FOS and LOS extracts at the highest concentration $(0.39 \mathrm{mg} / \mathrm{mL})$ (Figures 4(A) and 5(A). The lowest concentration (0.01 $\mathrm{mg} / \mathrm{mL}$ ) of both FOS and LOS still exhibited mild reduction which was less than $20 \%$. For pre-treatment assay, both FOS and LOS showed high activity which was $79 \%$ and $84 \%$, respectively, at highest concentration $(0.39 \mathrm{mg} / \mathrm{mL})$ (Figures 4(B) and 5(B)). Both extracts also displayed mild antiviral activity with less than $20 \%$ plaque reduction at the lowest concentration. The antiviral activity of FOS and LOS were observed to be concentration dependent as the percentage of plaque reduction is reduced with reducing OS concentration. In virucidal assays, exposure of HSV-1 to both FOS and LOS extracts at $0.39 \mathrm{mg} / \mathrm{mL}$ reduced $100 \%$ of virus titer at all time points (Figure $4(\mathrm{C})$ and $5(\mathrm{C})$ ). This result confirms the high virucidal activity observed in WPOS extract.

Effectiveness of certain compounds or extracts can be evaluated by using selective index (SI). The evaluation will take into account of the toxicity value as well as the antiviral concentration for specific cell line. Therefore, the SI was calculated for each part of OS in post-treatment and pre-treatment assay. Comparison of SI for all extracts between post-treatment and pre-treatment are shown in Tables 1 and 2. SI for post-treatment in all extracts showed high SI values compared to those obtained from pre-treatment assay.
TABLE 1. $\mathrm{CC}_{50}, \mathrm{EC}_{50}$ and SI values of all extracts in post-treatment

\begin{tabular}{lccc}
\hline & $\mathrm{CC}_{50}(\mathrm{mg} / \mathrm{mL})$ & $\mathrm{EC}_{50}(\mathrm{mg} / \mathrm{mL})$ & $\mathrm{SI}\left(\mathrm{CC}_{50} / \mathrm{EC}_{50}\right)$ \\
\hline FOS & 1.269 & 0.0735 & 17.27 \\
LOS & 0.844 & 0.044 & 19.18 \\
WPOS & 3.125 & 0.1953 & 16.00 \\
\hline
\end{tabular}

TABLE 2. $\mathrm{CC}_{50}, \mathrm{EC}_{50}$ and SI value of all extract in pre treatment

\begin{tabular}{lccc}
\hline & $\begin{array}{c}\mathrm{CC}_{50} \\
(\mathrm{mg} / \mathrm{mL})\end{array}$ & $\begin{array}{c}\mathrm{EC}_{50} \\
(\mathrm{mg} / \mathrm{mL})\end{array}$ & $\begin{array}{c}\mathrm{SI}(\mathrm{SI} \\
\left(\mathrm{CC}_{50} / \mathrm{EC}_{50}\right)\end{array}$ \\
\hline FOS & 1.269 & 0.325 & 3.9 \\
LOS & 0.844 & 0.183 & 4.6 \\
WPOS & 3.125 & - & - \\
\hline
\end{tabular}

\section{DISCUSSION}

Bioactive compound in plant refers to the secondary metabolites which elicit pharmacological or toxicological effects in different organisms. Plant secondary metabolites hold important functions in living plants such as in protecting the plants from harsh environment and in protecting systems (Bernhoft 2010). Based on phytochemical analyses, OS has been proven to be rich
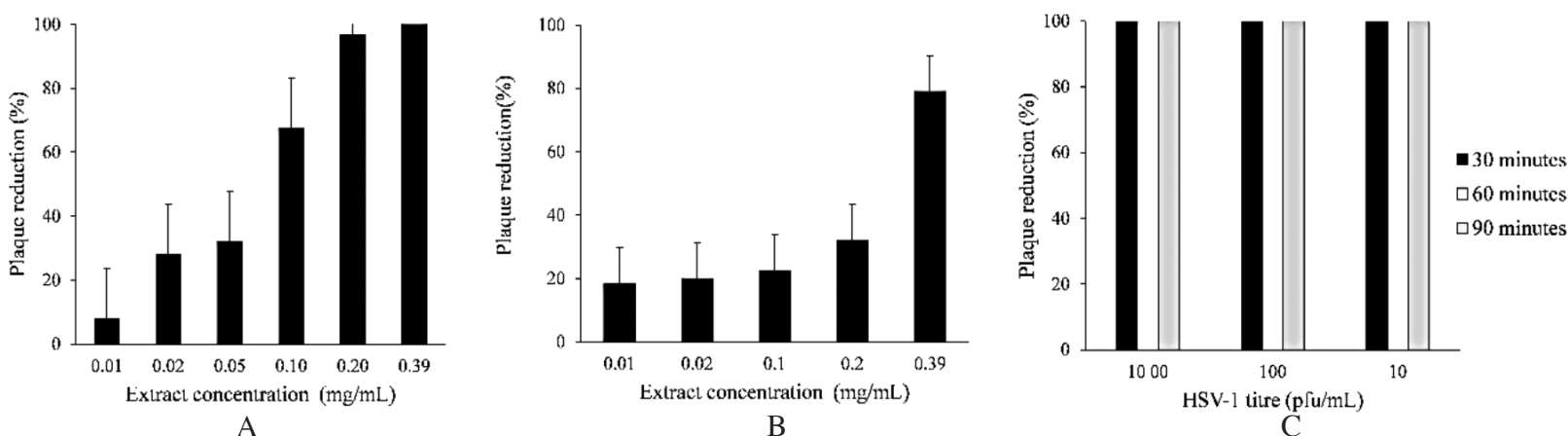

FIGURE 4. Antiviral activities of FOS extracts against HSV-1 via post-treatment assay

(A), pre-treatment assay (B) and viruidal assay (C)
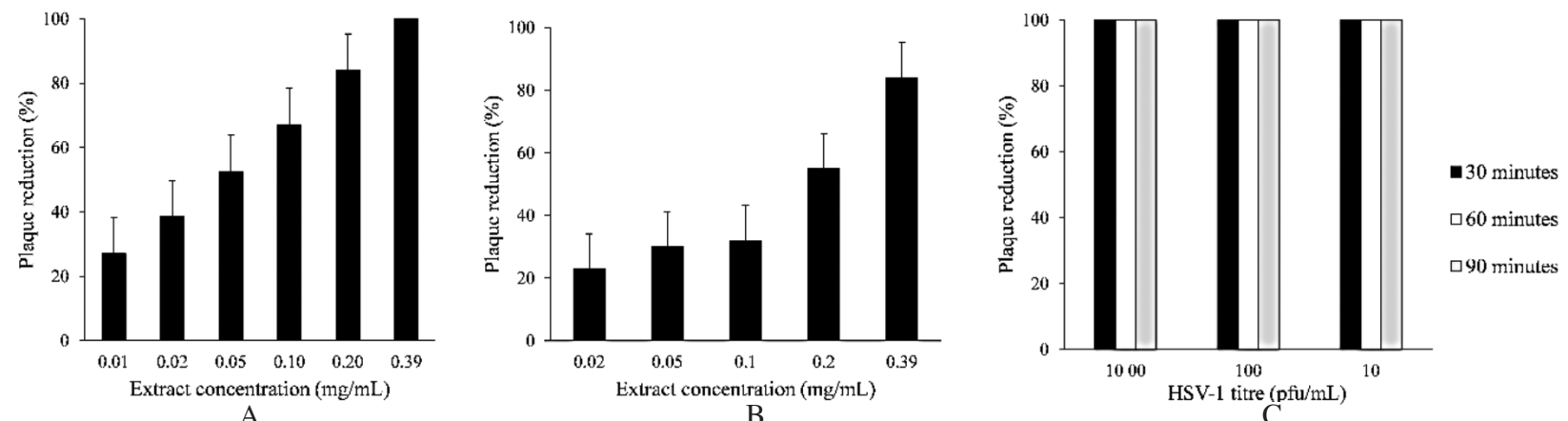

FIGURE 5. Antiviral activities of LOS extract against HSV-1 via post-treatment assay

(A), pre-treatment assay (B) and virucidal assay (C) 
in secondary metabolites such as glycosides, phenolic compound such as lipophilic flavones, flavonol glycosides and caffeic acid derivatives (Sumaryono et al. 1991), mono-, di- and sesqui-terpenoids (Tezuka et al. 2000). Previously, phytochemical analysis using high performance liquid chromatography (HPLC) by Hussin et al. (2013) showed aqueous extract of os leaves has various bioactive compounds such as phenolic acids (caffeic acid and rosmaarinic acid) and methoxylated flavones (sinensetin and eupatorin). Distribution of metabolites across different parts of the OS plant may contribute to the differences in toxicity profiles observed. This is in agreement with this study where different $\mathrm{CC}_{50}$ values were observed across WPOS, FOS and LOS extracts. The highest $\mathrm{CC}_{50}$ value was observed in WPOS extract followed by FOS and LOS extracts which indicates using whole plant extract is more toxic compared to using separate parts of the plant. Lyu et al. (2005) showed that flavanols, flavanones, isoflavones and flavonols inhibit HSV-1 in vitro via plaque reduction assay. Leaves of os have been reported by many researchers to be rich in flavonoid (Akowuah et. al 2004; Al-Suede et. al 2012; Hossain et al. 2013; Hussin et al. 2015). Thus, the richness of flavonoid in os leaves may contribute to anti-HSV-1 properties. Therefore, we hypothesized that OS exerts antiviral activity which lead us to screen the whole plant for its anti-HSV-1 activity.

In this study, antiviral screening was initially done on whole plant to evaluate the antiviral efficacy. High activity shown by whole plant has prompted us to further study this plant by evaluating the antiviral efficacy by different parts of the plant. Identifying the actual plant parts with high antiviral activity, will enable us to focus and maximize the antiviral activity study towards respected parts without wasting the whole plant.

When virus infects a cell, it causes morphological changes to the cell. In HSV-1 infection, it causes enlargement of cells from its original size which is known as cytopathic effect (CPE). However, when HSV-1 completed its replication cycle, it egresses from the cell by lysis to release the virus progeny. The lysis of cells caused by viral egression leaves a gap which is known as plaque. The progeny will then infect the surrounding cells and the process repeats, making the gap/plaque bigger. These are the basis of antiviral efficacy evaluation where inhibition of plaque indicates the inhibition of virus. The antiviral activity of WPOS, FOS and LOS extract were studied in the context of three main treatments which are post-, pre- and virucidal effect using plaque reduction assay. Plaque reduction assay is a quantitative measurement of the number of plaques that are formed by a virus at various dilutions (Smither et al. 2013).

Post-treatment was given after the adsorption of the virus onto the cell. Thus this assay was done to investigate the activity of the extracts in inhibiting viral replication cycle downstream of the HSV-1 entry process. The inhibition may exert at various stages of the viral replication cycle such as during the transcription of viral genes (immediate early gene, early gene, genome replication or late gene expression), envelopment process or during egression (Whitley et al. 1998). Pre-treatment was done to study the effect of the extract as prophylactic agent in protecting the cell from HSV-1 adsorption and penetration. Therefore, inhibition by os indicates that the extract can act as prophylactic agent to protect Vero cells against HSV-1 infection. The ability of the extract to act directly against HSV-1 virion particle was observed in virucidal assay. High titre of HSV-1 was challenged with specific concentration of OS extract. OS extract was observed to have $100 \%$ inhibition of HSV-1 infection regardless of duration of treatment. Titer reduction observed in virucidal assay might be due to direct effect of extract towards HSV-1 envelope or glycoproteins that lead to the failure of HSV-1 virion particles to adsorb and enter the cell after being exposed to OS. The same finding was reported by Schumacer et al. (2003). They demonstrated that peppermint oil extract has the ability to inhibit HSV-1 plaque formation in virucidal assay and they concluded that free HSV-1 particles are very sensitive towards the extract.

Both leaves and flower (LOS and FOS, respectively) showed high anti-HSV-1 activity. Post-treatment of OS has the potential to be exploited where the SI values were more than 10 in all extracts. Antiviral agent with SI value of more than 10 can be considered to possess high potential to be developed as antiviral (Dargan 1998). However, the results of SI for pre-treatment in all three extracts suggest that they are not suitable to be used as prophylactic agents. Although commercial antiviral drugs such as acyclovir, penciclovir, valaciclovir and foscarnet have high SI value and are major regimes for anti-HSV-1 treatments, they do not exert virucidal activity against HSV-1 (Arvin et al. 2007). It is a big advantage for an antiviral drug to exhibit virucidal activity as well, as it would directly affect the virus without affecting the cells. It is also important to have antiviral drugs that possess different antiviral mechanisms as HSV-1 has conferred resistant towards currently available commercial drugs.

A commercially available herbal medicine known as Setarud (IMODTM) that has been used intravenously to treat human immunodeficiency virus (HIV) was proven to inhibit HSV-1 by virucidal effect (Zabihollahi et al. 2012). However, the inhibition percentage of this herbal medicine $(54 \%)$ was lower than that of OS extracts which shows $100 \%$ inhibition. Collectively, OS extracts showed ability in different type of antiviral treatments unlike commercial drugs which usually only focus on one treatment.

\section{CONCLUSION}

This study demonstrates the ability of $O$. stamineus aqueous extract as a novel anti-HSV-1 agent via posttreatment, pre-treatment as well as virucidal assay. All the conducted assays proved high percentage of plaque and viral titre reduction in infected cells after exposure to the extracts. LOS exhibited lower cytotoxicity compared to the other two extracts. This implies that LOS might be more suitable to be used as a long-term regime in combating HSV- 
1 infection. Although plaque reduction assays exhibited promising antiviral properties of os extracts, further studies are required to explore the underlying mechanisms that contribute to its antiviral activity.

\section{ACKNOWLEDGEMENTS}

We wish to thank Universiti Kebangsaan Malaysia (UKM), Faculty of Science and Technology and School of Biosciences and Biotechnology, UKM for the facilities and laboratory instruments as well as Ladang Herba Ya'acob Berkat, Bukit Katil, Melaka for the source of dried os plant. We would also like to thank GGPM-2012-108 for funding part of the project.

\section{REFERENCES}

Akowuah, G.A., Ismail,Z., Norhayati, I. \& Sadikun, A. 2005. The effects of different extraction solvents of varying polarities on polyphenols of Orthosiphon stamineus and evaluation of the free radical-scavenging activity. Food Chemistry 93(2): 311-317.

Amzad, H.M. \& Ismail, Z. 2012. Quantification and enrichment of sinensetin in the leaves of Orthosiphon stamineus. Arabian Journal of Chemistry 9: S1338-S1341.

Al-suede, F.S.R., Farsi, E., Ahamed, M.B.K., Ismail, Z., Majid, S.A. \& Majid, A.M.S.A. 2012. Marked antitumor activity of cat's whiskers tea (Orthosiphon stamineus) extract in orthotopic model of human colon tumor in nude mice. Journal of Biochemical Technology 3(5): 170-176.

Arvin, A., Campadelli-Fiume, G., Mocarski, E., Moore, P.S., Roizman, B., Whitley, R. \& Yamanishi, K. 2007. Human Herpesviruses: Biology, Therapy, and Immunoprophylaxis. Cambridge: Cambridge University Press.

Bernhoft, A. 2010. A brief review on bioactive compounds in plants. Bioactive compounds in plants - benefits and risks for man and animals. Proceedings from a Symposium Held at The Norwegian Academy of Science and Letters, Oslo, 13 - 14 November 2008. pp. 11-17.

Dargan, D.J. 1998. Methods in Molecular Medicine. Totowa, New Jersey: Humana Press.

Ho, C.H., Noryati, I., Sulaiman, S.F. \& Rosma, A. 2010. In vitro antibacterial and antioxidant activities of Orthosiphon stamineus Benth. Extracts against food-borne bacteria. Food Chemistry 122(2010): 1168-1172.

Hossain, M.A., Ismail, Z, Rahman, A. \& Kang, S.C. 2008. Chemical composition and anti fungal properties of the essential oils and crude extracts of Orthosiphon stamineus Benth. Industrial Crops and Products 27(2008): 328-334.

Hussin, M.A. \& Mizanur Rahman, S.M. 2013. Isolation and characterisation of flavonoids from the leaves of medicinal plant Orthosiphon stamineus. Arabian Journal of Chemistry 8(2): 218-221.

Li, T.S.C. 2000. Medicinal Plants Culture, Utilization and Phytopharmacology. Lancaster, Pennsylvania: Technomic Publishing Company.

Lyu, S.Y., Rhim, J.Y. \& Park, W.B. 2005. Antiherpetic activities of flavonoids against herpes simplex virus type 1 (HSV1) and type 2 (HSV-2) in vitro. Archives of Pharmacal Research 28(11): 1293-1301.
Mosmann, T. 1983. Rapid colorimetric assay for cellular growth and survival: Application to proliferation and cytotoxicity assays. Journal of Immunological Methods 65: 55-63.

Nguyen, M.L., Kraft, R.M. \& Blaho, J.A. 2005. African green monkey kidney Vero cells require de novo protein synthesis for efficient herpes simplex virus 1 - dependent apoptosis. Virology 336: 274-290.

Roizman, B. \& Knipe, D.M. 1993. The Replication of Herpes Simplex Virus. 4th. ed. New York: Lippincott Press.

Schnipper, L.E. 1980. Resistance of herpes simplex virus to acycloguanosine: Role of viral thymidine kinase and DNA polymerase loci. Proceedings of the National Academy of Science of the United States of America. pp. 2270-2273.

Schuhmacher, A., Reichling, J. \& Schnitzler, P. 2003. Virucidal effect of peppermint oil on the enveloped viruses herpes simplex virus type 1 and type 2 in vitro. Phytomedicine 10: 504-510.

Shogan, B., Kruse, L., Mulamba, G.B., Hu, A. \& Coen, D.M. 2006. Virucidal activity of a GT-rich oligonucleotide against herpes simplex virus mediated by glycoprotein B. Journal of Virology 80(10): 4740-4747.

Smither, S.J., Lear-rooney, C., Biggins, J., Pettitt, J., Lever, M.S. \& Olinger, G.G. 2013. Comparison of the plaque assay and $50 \%$ tissue culture infectious dose assay as methods for measuring filovirus infectivity. Journal of Virological Methods 193(2): 565-571.

Sumaryono, W., Proksch, P., Wray, V., Witte, L. \& Hartmann, T. 1991. Qualitative and quantitative analysis of the phenolic constituents from Orthosiphon aristatus. Planta Medica 57: 176-180.

Tezuka, Y., Stampoulis, P., Banskota, A.H.,Awale, S., Tran, K.Q., Saiki, I. \& Kadota, S. 2000. Constituents of the Vietnamase medical plant Orthosiphon stamineus. Chemical and Pharmaceutical Bulletin 48: 1711-1719.

Whitley, R.J. \& Roizman, B. 2001. Herpes simplex virus infections. Lancet 357(9267): 1513-1518.

Whitley, R.J., Kimberlin, D.W. \& Roizman, B. 1998. Herpes simplex viruses. Clinical Infectious Diseases 26(3): 541-555.

Zabihollahi, R., Namazi, R., Aghasadeghi, M.R., Esfahani,A.F., Sadat, S.M. \& Modarressi, M.H. 2012. The in vitro antiviral potential of Setarud (IMOD ${ }^{\mathrm{TM}}$ ), a commercial herbal medicine with protective activity against acquired immune deficiency syndrome in clinical trials. Indian Journal of Pharmacology 44(4): 448-453.

School of Biosciences and Biotechnology

Faculty of Science and Technology

Universiti Kebangsaan Malaysia

43600 UKM Bangi, Selangor Darul Ehsan

Malaysia

*Corresponding author; email: efrina@ukm.edu.my

Received: 14 September 2017

Accepted: 17 April 2018 